\title{
Rising Star Exchange: An Alternative Capital Market for SME in Indonesia
}

\author{
Masripah \\ masripah@upnvj.ac.id \\ Meizaroh \\ mei@operbisnis.com \\ OperBisnis
Alvita Yuniar
alvita@operbisnis.com
OperBisnis \\ Pramuditya Ardhana \\ pramuditya@operbisnis.com \\ OperBisnis
}

Program Studi Akuntansi, Fakultas Ekonomi dan Bisnis

Universitas Pembangunan Nasional Veteran Jakarta, Jakarta, Indonesia

\begin{abstract}
The purpose of this paper is to formulate an ideal stock exchange to help Small-Medium Entity (SMEs) in getting the capital they need. SMEs face some difficulties to grow its business. Access to the capital market is one of their main obstacles. This research uses a descriptive approach. This research discusses the problem by using literature study and secondary data as a source of information which is then analysed to be interpreted. This paper analyses both equity crowdfunding and Indonesian Stock Exchange Acceleration Board as the currently available equity market for SMEs. The key takeaways from both capital markets then being used to develop a new capital market called Rising Star Exchange (RiSE). The results of this paper implicate that by having this stock exchange, SMEs will have better access to funding while the investors also get the level of protection they need. The paper contributes to the social, economic and business sciences. The results of this paper could be used by the government to formulate a regulatory environment which could support the growth of SMEs, by the SMEs to find another alternative source of fund, and by the investors to allocate their fund in SMEs investment.
\end{abstract}

Keywords: SMEs; equity crowdfunding; stock exchange

\begin{abstract}
Abstrak
Penelitian ini bertujuan untuk merumuskan bursa efek yang ideal untuk membantu Usaha Kecil Menengah (UKM) dalam mendapatkan modal yang dibutuhkan. UKM menghadapi beberapa kesulitan untuk mengembangkan usahanya. Akses ke pasar modal menjadi salah satu kendala utama mereka. Penelitian ini menggunakan pendekatan deskriptif. Penelitian ini membahas masalah yang ada dengan menggunakan studi Pustaka dan data sekunder sebagai sumber informasi yang kemudian dianalisis untuk diinterpretasikan. Penelitian ini menganalisis crowdfunding ekuitas dan Dewan Akselerasi Bursa Efek Indonesia sebagai pasar ekuitas yang tersedia saat ini untuk UKM. Poin utama dari kedua pasar modal ini kemudian digunakan untuk mengembangkan pasar modal baru yang disebut Rising Star
\end{abstract}


Exchange (RiSE). Hasil dari penelitian ini berimplikasi bahwa dengan adanya bursa saham ini, UKM akan memiliki akses pendanaan yang lebih baik sementara investor juga mendapatkan tingkat proteksi yang mereka butuhkan. Penelitian ini berkontribusi pada ilmu sosial, ekonomi, dan bisnis. Hasil dari penlitian ini dapat digunakan oleh pemerintah untuk merumuskan regulasi lingkungan yang dapat mendukung pertumbuhan UKM, oleh UKM untuk mencari alternatif sumber dana lain, dan oleh investor untuk mengalokasikan dananya dalam investasi UKM.

Kata kunci: UKM; crowdfunding ekuitas; bursa efek

\section{INTRODUCTION}

Micro-Small-Medium Entity (MSMEs) has been known as the backbone of Indonesia economy. Ministry of Cooperatives and SMEs defines MSMEs according to their assets excluding land and building and annual sales as mentioned in Table 1. In 2010, BPS recorded 52.8 million MSMEs in Indonesia which increase to 64.2 million in 2018. Supporting MSMEs would bring an impact to support Indonesia economy.

Table 1. Definition of MSMEs in Indonesia

\begin{tabular}{lrr}
\hline & Assets (excluding land and building) & \multicolumn{1}{c}{ Annual Sales } \\
\hline Micro & $<50$ million IDR & $<300$ million IDR \\
Small & $50-500$ million IDR & 300 million $-2,5$ billion \\
IDR \\
Medium & 500 million -10 billion IDR & 2.5 billion -50 billion \\
IDR
\end{tabular}

Source: SME Law 20/2008, Ministry of Cooperatives and SMEs

According to BPS, MSMEs contributes to $61.07 \%$ to the Gross Domestic Product (GDP) and absorb $97 \%$ of the Indonesian workforce in 2018. Research by SME Centre of Economy and Business Faculty of University of Indonesia (2018) found that there are two main obstacles faced by MSMEs in Indonesia, those are funding access and marketing. Difficulty in obtaining financial support hinders MSMEs from expanding their businesses.

Table 2. MSMEs Growth for The Past 5 Years

\begin{tabular}{|c|c|c|c|c|c|c|}
\hline \multirow[t]{2}{*}{ Category } & \multicolumn{2}{|l|}{2012} & \multicolumn{2}{|l|}{2013} & \multicolumn{2}{|l|}{2014} \\
\hline & Number & $\%$ & Number & $\%$ & Number & $\%$ \\
\hline Business & & & & & & \\
\hline $\begin{array}{l}\text { Unit } \\
(\mathrm{A}+\mathrm{B})\end{array}$ & $55,211,396$ & & $56,539,559$ & & $57,900,787$ & \\
\hline $\begin{array}{l}\text { A. } \\
\text { MSME }\end{array}$ & $55,206,444$ & 100 & $56,534,591$ & 100 & $57,895,721$ & 100 \\
\hline Micro & $54,559,969$ & 99.8 & $55,856,176$ & 98.8 & $57,189,393$ & 98.8 \\
\hline Small & 602,195 & 1.09 & 629,418 & 1.11 & 654,222 & 1.13 \\
\hline
\end{tabular}




\begin{tabular}{crrrrrr} 
Medium & 44,280 & 0.08 & 48,997 & 0.01 & 52,106 & 0.09 \\
B. Big & 4,952 & 0.01 & 4,968 & 0.01 & 5,066 & 0.01 \\
\cline { 2 - 4 } & Source: & Ministry of Cooperatives and Small and Medium Enterprises (Kemenkop UKM)
\end{tabular}

Table 2. MSMEs Growth for The Past 5 Years (continued)

\begin{tabular}{|c|c|c|c|c|c|c|c|c|}
\hline \multirow[t]{2}{*}{ Category } & \multicolumn{2}{|l|}{2015} & \multicolumn{2}{|l|}{2016} & \multicolumn{2}{|l|}{2017} & \multicolumn{2}{|c|}{$\begin{array}{c}\text { Growth } \\
2012-2017\end{array}$} \\
\hline & Number & $\%$ & Number & $\%$ & Number & $\%$ & Number & $\%$ \\
\hline Business & & & & & & & & \\
\hline $\begin{array}{l}\text { Unit } \\
(\mathrm{A}+\mathrm{B})\end{array}$ & $59,267,759$ & & $61,656,546$ & & $62,928,077$ & & $7,716,681$ & 14 \\
\hline $\begin{array}{l}\text { A. } \\
\text { MSME }\end{array}$ & $59,262,772$ & 100 & $61,651,176$ & 100 & $62,922,617$ & 100 & $7,716,173$ & 14 \\
\hline Micro & $58,521,987$ & 98.7 & $60,863,578$ & 98.7 & $62,106,900$ & 98.7 & $7,546,931$ & 13.8 \\
\hline Small & 681,522 & 1.15 & 731,047 & 1.19 & 757,090 & 1.2 & 154,895 & 25.7 \\
\hline Medium & 59,263 & 0.1 & 56,551 & 0.09 & 58,627 & 0.09 & 14,347 & 32.4 \\
\hline B. Big & 4,987 & 0.01 & 5,370 & 0.01 & 5,460 & 0.01 & 508 & 10.3 \\
\hline
\end{tabular}

Source: Ministry of Cooperatives and Small and Medium Enterprises (Kemenkop UKM)

Until the last two years, the trend of MSME financing has relied solely on the banking sector. The potential that exists in other sectors is quite open with a wider reach. According to Sigar (2012), small companies only have a few options for financing. Bank financing could be a difficult option due to lack of asset to be used as collateral and only being established in a few years which give them a short track record.

The crowdlending industry tries to provide MSMEs with a source of capital they need. Their presence has brought tremendous impact on the business development of those MSMEs. However, crowdlending or peer-to-peer (P2P) lending only bridges the MSMEs to debtors. It does not allow the investor to fund the MSMEs in the form of equity. It also does not provide an exit way for the entrepreneurs who decide to sell their stake either the full shares or just part of it. Having other shareholders on board also has been known as a way to increase the quality of corporate governance.

In a micro business, it is more difficult to finance than the small and medium businesses since their lack of legal form. Due to the very small size, usually the micro businesses are sole proprietorship. Hence, such financing activities like in crowdlending might suit them more while small and medium businesses might be able to get another alternative of funding. Thus, this paper tries to formulate an ideal capital market for SMEs where they could share their ownership with other potential investors and get the fund they need.

\section{LITERATURE REVIEW}

According to the Law for SMEs, the definition of micro, small and medium enterprises is:

a. Micro Enterprises are productive businesses owned by individuals and / or individual business entities that meet the criteria for Micro Business as regulated in this Law.

b. Small business is a stand-alone productive economic, which carried out by individuals and/or a business entity that is not a subsidiary or branch of an owned, controlled, or as a part of either directly or indirectly, of a medium or large business that meets the criteria for Small Business as regulated in this Law.

c. Medium business is a stand-alone productive economic, which carried out by individuals and/or a business entity that is not a subsidiary or branch of an owned, 
controlled, or as a part of either directly or indirectly, of a medium or large business with a total net worth or annual sales as regulated in this Law.

Equity Crowdfunding is the provision of share offering services carried out by issuers to sell shares directly to investors through an open electronic system network (POJK No.37 of 2018 article 1). According to Tripalupi (2019), SMEs need to consider equity crowdfunding compared to peer-to-peer lending because the costs are relatively cheaper. Equity crowdfunding is a type of funding without burdening the obligation to pay interest and principal of funding. Fundraising companies (which its function almost the same as securities companies in the primary market) only need to offer a portion of the shares issued by SMEs as compensation for the investment given. That way investors will get a portion of the SME ownership and will receive returns in the form of dividends from SMEs according to the size of the shares they have.

Equity crowdfunding in Indonesia is a form of financial service activity in the capital market. However, in the equity crowdfunding scheme, SMEs are not required to go through an Initial Public Offering (IPO) process or conduct a public offering of their shares on the Indonesia Stock Exchange (IDX). This is in accordance with POJK No. 37 of 2018 article 5, namely the offering of shares by each issuer through equity crowdfunding is not a public offering as referred to in the Law of the Republic of Indonesia (UURI) Number 8 of 1995 concerning the Capital Market.

The capital market bridges the fund owners and the parties who are raising funds for medium and long-term investment purposes (Nasarudin et. Al., 2014: 10). Both parties make a sale and purchase of capital in the form of securities. The owner of the funds submits a number of funds and the recipient of the funds (public company) submits a proof of ownership in the form of securities. According to the Capital Market Law Article 1 point 4, a Stock Exchange is a Party that organizes and provides a system and / or means of bringing together the buying and selling offers of other Parties for the purpose of trading Securities between them.

Harwood and Konidaris (2015) mentioned that some countries and exchanges have contacted the World Bank Group (WBG) requesting to help them developing SME exchange. Some developed countries have shown some successes in developing such exchange. Due to much smaller size of SMEs in emerging market, developing an SMEs exchange becomes more difficult. However, some developing countries have exhibited a success in developing SMEs exchange. Hence, this paper is conducted to answer below question: what is the ideal SMEs stock exchange for Indonesia?

\section{RESEARCH METHOD}

This research uses a descriptive approach. Narbuko and Achmadi (2009: 44) state that descriptive research is a study that seeks to solve problems based on existing data and involves data presentation, data analysis and interpretation of analysis results.

This research discusses the problem by using literature review and secondary data as a source of information which is then analysed to be interpreted. This method involves collecting, evaluating and analysing publications that relate to the research question. The data used in this research are current SMEs condition such as its growth and difficulties to further grow, existing regulations and capital market structure both in Indonesia and other countries. Those data are retrieved from the related organization and government institution website. The literature review is used to conduct an evaluation of the state of SMEs problem in 
Indonesia and formulate a possible solution. Starting from this, things are arranged that can be a solution to existing problems.

\section{RESULT AND DISCUSSION}

\section{Investment Ecosystem}

With a population of over 261 million, Indonesia is the largest homogenous consumer market in Southeast Asia. Businesses in Indonesia might have more opportunities to scale up for a meaningful development towards the domestic market, go digital and be able to adapt with the social, economic and political condition. The optimism for better investment ecosystem is supported by the data of Google-A.T. Kearney Study (2017) predicts that the banked population to be more than doubled from 88 million people in 2016 to 150 million people in 2021, smartphone penetration to be increased significantly from 85 million users in 2016 to 148 million in 2021 and online shopper base to be boosted from only 11 million people in 2016 to 42 million in 2021.

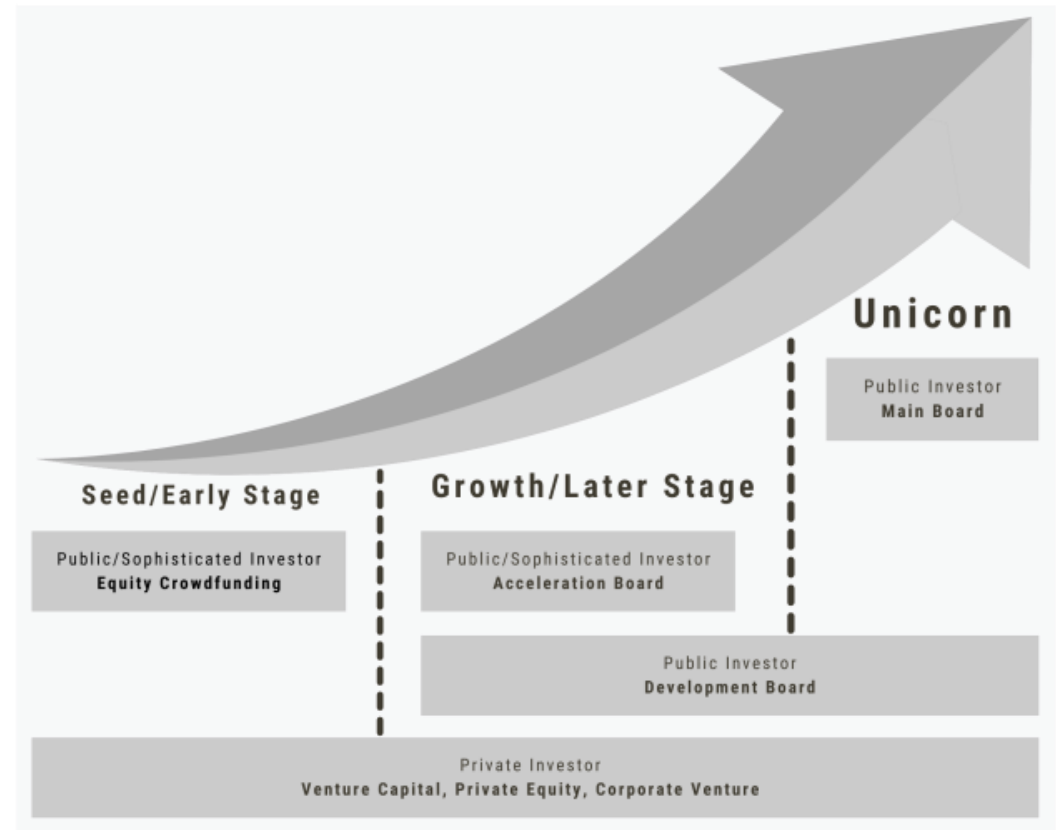

Figure 1. Investment Ecosystem

Source: IDX

There are several ways for a business to raise capital. However, due to the higher risk, seed / early-stage financing is the least favourable investment for some parties. Private investors' investment criteria are based on the potential of the company to grow fast within a limited period and resources. Private investors such as venture capital and private equity have a minimum ticket size amounting USD 500,000 (around IDR 7.5 billion translated using the exchange rate on September 8, 2020) and require an exit option for most of their investment. According to Wilson and Silvia (2013), venture capitalists already have an exit strategy formulated at the beginning of the investment. However, formulating an exit strategy for SMEs investment is difficult to do. Legland (2016) researched in Finland comparing investment in equity crowdfunding and stock exchange which found that investors in equity crowdfunding suffered a significant loss while the investors in stock exchange received positive returns. Hence, those private investors are hardly an alternative source of funding for SMEs. 
Development board has more requirements compared to acceleration board and has a more expensive fee according to IDX Fact Book (2019). Due to the requirement that the issuer who wants to be listed in development board should have a full commitment underwriter agreement rather than a best effort agreement, the issuer would have to pay a higher cost as well. Thus, it leaves equity crowdfunding and acceleration board as the possible equity capital market for SMEs.

\section{Equity Crowdfunding and Indonesia Stock Exchange}

According to Goldman Sachs (2015), in the United States of America, crowdfunding was primarily found as a platform to support donation and charity fundraising. It then progressed to a rewards platform and with a gradually encouraging regulation from the government, it developed to an equity investment platform. One factor that enables this transformation in a short time is the strong network effects. Campaign done by the entrepreneurs who are seeking funds attracts people to check on the project and interested people will back the campaign by sharing the project on their social media. Kuppuswamy and Bayus (2013) found that investors in crowdfunding platform tend to make their decision by following other investors. With this kind of network, the funders could grow exponentially.

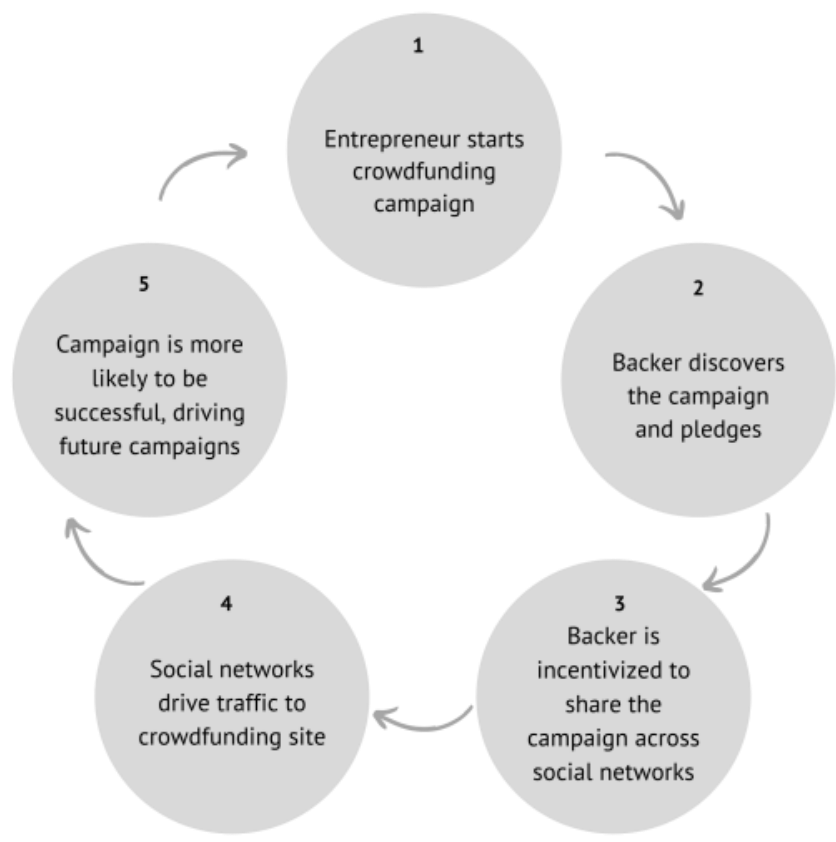

Figure 2. Crowdfunding benefits from strong network effects Source: Goldman Sachs Global Investment Research (2015)

In Indonesia, equity crowdfunding is regulated by Indonesia Financial Services Authority (OJK) through its regulation POJK No. 37/POJK04/2018. The first equity crowdfunding authorized by OJK was PT Santara Daya Inspiratama in September 2019. As of September 10,2020 , Santara reported on its website that they have received 5,887 business proposals in their platform. It describes how much SMEs in Indonesia needs an equity market. According to Legland (2016), equity crowdfunding can be perceived as being affiliated to the lowest level of the equity exchange ladder.

On 22 July 2019, the Indonesia Stock Exchange (IDX) also launched an acceleration board to help SMEs in accessing a broader capital market. The businesses targeted by the acceleration board could be divided into two groups based on categories set by regulation POJK No. 53/POJK.04/2017, small scale issuer and medium scale issuers. Small scale issuer 
should have total assets equal or less than IDR 50 billion, while medium-scale issuers should have total assets between IDR 50 billion and equal or less than IDR 250 billion. According to SME Law 20/2008, small and medium businesses have a total assets maximum to IDR 10 billion. Thus, acceleration board could not capture this market yet. Compared to equity crowdfunding, the acceleration board has not attracted a lot of SMEs to be listed.

Besides several differences between equity crowdfunding and IDX acceleration board, these three differences could be summarized from POJK No. 37/POJK04/2018 which regulates the equity crowdfunding and POJK No. 53/POJK.04/2017 which regulates the IDX acceleration board.

Table 3. Differences between equity crowdfunding and IDX acceleration board

\begin{tabular}{|c|c|c|}
\hline Requirements & Equity Crowdfunding & IDX Acceleration Board \\
\hline Number of shareholders & $<300$ parties & $\geq 300$ parties \\
\hline Fund-raised & Max IDR 10 billion & $\begin{array}{r}\text { Max IDR } 50 \text { billion for } \\
\text { small business }\end{array}$ \\
\hline $\begin{array}{l}\text { Provide secondary } \\
\text { market }\end{array}$ & Yes & Yes \\
\hline Function & $\begin{array}{r}\text { Marketplace and arranger of } \\
\text { the public offering }\end{array}$ & Merely a marketplace \\
\hline $\begin{array}{l}\text { Arranger of the public } \\
\text { offering }\end{array}$ & Internal & Hired by the issuer \\
\hline
\end{tabular}

Source: summarized by authors

According to Wilson and Testoni (2014), despite the efficient feature of equity crowdfunding, information asymmetry which is a common problem in seed and early-stage financing exacerbated in equity crowdfunding making the investment to be even riskier.

Most of the equity crowdfunding in Indonesia currently only works for initial public offering. Most of them do not provide a marketplace for investors to resale their ownership. The illiquidity of equity crowdfunding investment makes it unfavourable for the society to invest in the platform. Since reselling the shares requires the shareholders to find potential buyers by themselves, exiting this investment is perceived to be very difficult. Despite the inactivity of the market, IDX acceleration board as a stock exchange provides a platform for the secondary market to happen.

According to POJK No. 37/POJK04/2018, an equity crowdfunding is required to have qualified employees in the field of legal compliance, finance and IT since besides providing a platform, they are also responsible in arranging the public offering. However, stock exchange functions as merely a marketplace. The issuer should hire some services provider such as underwriter, public accountant, lawyer, appraiser, and notary themselves. It makes listing in IDX to be more expensive compared to listing in equity crowdfunding.

\section{Emerging Market Index in Other Countries}

Table 4 showed the SMEs Exchange Board outlook globally. One of the oldest stock exchanges for SMEs and growing start-up were from the United Kingdom and Japan. In 2010, Chinext was formed as the subsidiary of the Shenzhen Stock Exchange and now has surpassed the total listing in Japan. In Southeast Asia, NSE Emerge was established in India in 2012 and Singapore (Catalist) in 2007, following with Malaysia (LEAP) that was established in 2017. The initiative of each country to establish the SME Exchange is also based on the number of SMEs in the country, their contribution towards the economy and human resources, and to solve financial problems that are usually faced by SMEs. 
Table 4. Emerging Market Index in Other Countries

\begin{tabular}{|c|c|c|c|c|}
\hline Country & SME Exchange & $\begin{array}{c}\text { Years } \\
\text { Established }\end{array}$ & Total Listing & $\begin{array}{l}\text { Total Market } \\
\text { Capitalization }\end{array}$ \\
\hline China & Chinext & 2009 & 807 (2020) & $\begin{array}{r}6.78 \text { trillion } \\
\text { yuan }\end{array}$ \\
\hline India & NSE Emerge & 2012 & $200(2020)$ & Rs 3,136 crore \\
\hline Japan & MOTHERS & 1999 & $\begin{array}{r}328 \text { (per Sept } \\
2020)\end{array}$ & $\begin{array}{l}8,415,495 \text { JPY } \\
\text { (August 2020) }\end{array}$ \\
\hline Singapore & CataList & 2007 & $\begin{array}{r}200 \text { (per end } \\
2017)\end{array}$ & SGD 12.8 billion \\
\hline Malaysia & $\begin{array}{l}\text { Bursa Malaysia LEAP } \\
\text { Market - Bursa } \\
\text { Marketplace }\end{array}$ & 2017 & $32(2020)$ & $\mathrm{N} / \mathrm{A}$ \\
\hline UK & $\begin{array}{l}\text { Alternative Investment } \\
\text { Market }\end{array}$ & 1995 & $1,254(2020)$ & N/A \\
\hline
\end{tabular}

There is no standard definition of what constitutes the regulation of SMEs, as the classification of SMEs might be different for each country. Here are some key takeaways of the countries' regulation:

1. A simple process of registration;

2. Fewer criteria for SMEs in terms of corporate governance and operational;

3. Role of advisers;

4. Less amount of share price standard;

5. Post-listing to be transferred to other board.

Table 5. Regulation overview of global SME Exchange

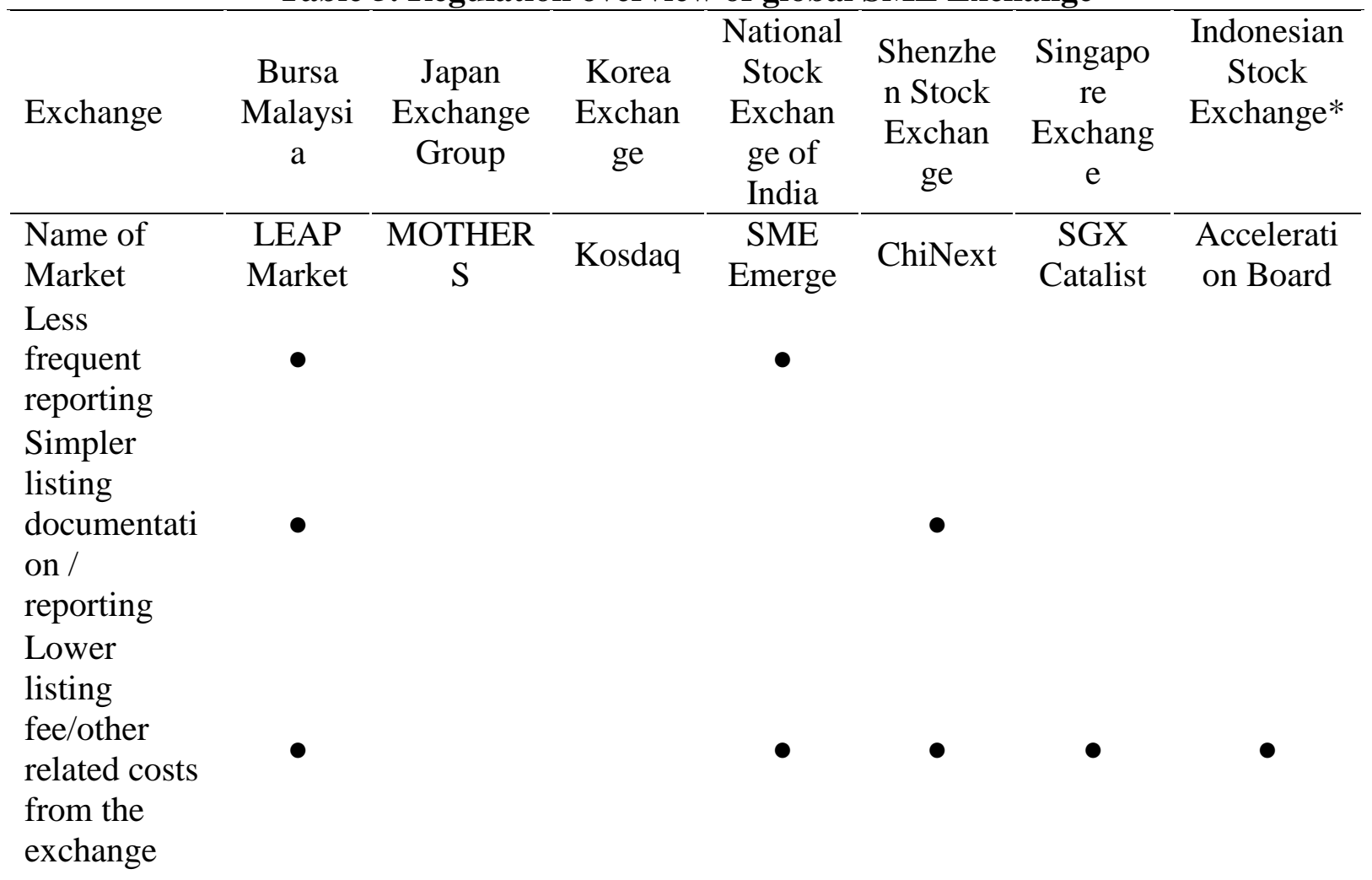

DOI: http://dx.doi.org/10.33021/jaaf.v\%vi\%i.1328 
Relaxed

business

records/

profits

requirements

Streamlined

listing

process

Compulsory

market

making

Exemption

from

regulatory

approval

Advisor-

driven

listings

Relaxed

requirements

on corporate

governance

codes

Additional

support for

SME listings

Source: * composed by author and the remaining is summarized from The World Federation of Exchanges (2018)

Compared to above countries, the IDX acceleration board which was launched in 2019 are still left behind in term of infrastructure and number of SMEs joining the board. According to Jakarta Post as of December 18, 2019, there were 17 SMEs listed in IDX acceleration board while equity crowdfunding platforms received more traction.

\section{Proposed Solution}

Indonesian SMEs need a stock exchange that could capture their characters and capital needs better. Rising Star Exchange (RiSE) is the ideal stock exchange proposed by this paper based on the analysis of both equity crowdfunding and IDX acceleration board.

Table 6. Rising Star Exchange

\begin{tabular}{lr}
\hline \multicolumn{1}{c}{ Requirements } & \multicolumn{1}{c}{ RiSE } \\
\hline $\begin{array}{l}\text { Number of shareholders } \\
\text { Fundraised } \\
\text { Provide secondary } \\
\text { market } \\
\text { Function }\end{array} \quad$ Yes \\
Arranger of the public & $\begin{array}{r}\text { Marketplace and arranger of } \\
\text { the public offering }\end{array}$ \\
\hline
\end{tabular}




$\begin{array}{r}\text { offering } \begin{array}{r}\text { arranger and 3rd parties hired } \\ \text { by the issuer }\end{array} \\ \hline \text { Source: Composed by authors }\end{array}$

Source: Composed by authors

To gather IDR 10 billion in an equity crowdfunding platform, unless a big investor is taking a big chunk of the investment opportunity, the average individual investors should invest around IDR 33.3 million. According to BPS as stated by Victoria (2020), the average income per capita of Indonesian citizen in 2019 was IDR 59.1 million. This means the average ticket size to raise IDR 10 billion funds in equity crowdfunding platform is more than half year income of average Indonesian citizen. By having a smaller ticket size in addition to having certain criteria for qualified investors, would reduce the risk bear by the individual investors and provide larger access to funding to SMEs.

According to Agrawal et al. (2013), both the equity crowdfunding platform and entrepreneurs are typically over-optimistic about potential outcomes. Having its own team doing the due diligence of the potentially listed company would help the issuer to reduce the cost of the public offering. However, having an underwriter and other supporting services provider in the issuer's team could also be beneficial for the issuer. While RiSE would maintain high integrity and qualified team to perform due diligence, RiSE would also allow qualified team licensed by the OJK to also be the arranger in the platform. It will enable cross-platform investment in the future.

Several technologies would also be added to the RiSE to increase its protection to shareholders while keeping its efficiency.

- E-voting

Research performed in the United Kingdom by Estrin et al. (2018) found that high-value investors communicated their frustration towards the companies listed in equity crowdfunding about the insufficient regular updates and general quality of feedback to the investors. While companies can set an investment threshold under which no voting rights are granted, having an e-voting system could help especially high-value investors to voice their concerns. This system might also enable shareholder activism to happen in the platform. According to Ertimur et al. (2011), shareholder activism takes a role in monitoring the managers of underperforming firms.

- Co-investment scheme

According to Wislon and Testoni (2014), the average individual investors are not aware of the risk of fallacy in success rates and returns on investment in start-ups. According to Agrawal et al. (2016), having qualified investors co-investing in the platform will help the due diligence process in the new investment. Thus, individual investors could also benchmark their decision to these professional investors.

- Blockchain technology

According to Schwienbacher (2019), blockchain technology might help investors to have an exit option. Currently, blockchain has been widely used to reduce transaction costs using its smart contract features. But it can also be used to facilitate the development of a secondary market. In December 2017, France government adopted a decree that allows blockchain technology as the media to record and transfer the financial securities.

To maintain the integrity of RiSE, several parties should be involved. Since RiSE stands in the middle of the equity crowdfunding and the acceleration board, OJK has to formulate a new regulation which could better facilitate for such exchange to happen. RiSE would also 
need support from other institutions such as the supporting professions and central securities depository to build the integrity of the capital market.

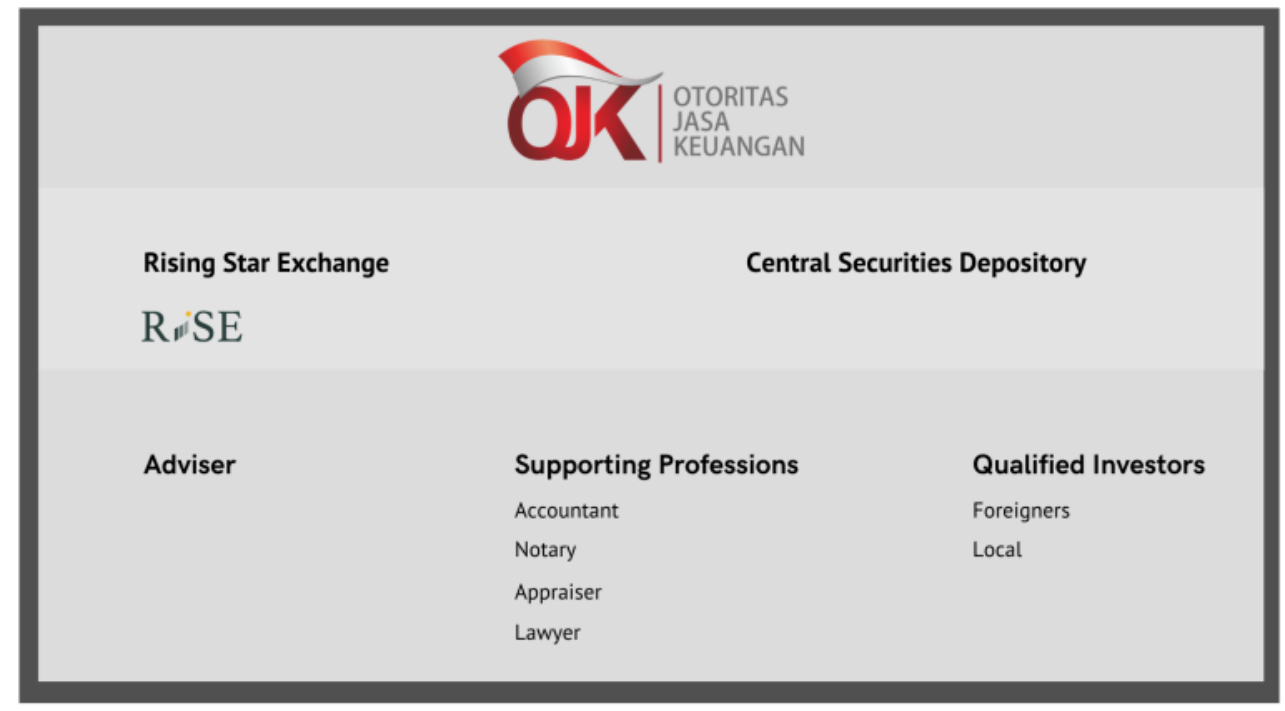

Figure 3. Parties Involved in RiSE

Source: composed by authors.

\section{CONCLUSION}

Providing SMEs with the access of fund could be remarkable support for their growth which will lead to increase in Indonesia GDP as well. However, the current capital market still gives some rooms for improvement. Equity crowdfunding is known to be easier to be entered compared to the acceleration board, but still needs some features for the benefits of the investor namely the transparency and exit option for the shareholders. The acceleration board provides such benefits but the higher level of regulation and its nature as merely a marketplace for the public offering, to be listed in the acceleration board is perceived to be more difficult and costly. Furthermore, IDX acceleration board requirement of total assets of the to be listed companies is much higher than criteria of SMEs by SME Law 20/2008. Thus, acceleration board could not capture this market yet. The results of this paper indicate that by having a stock exchange for SMEs, they will have better access to funding while the investors also get the level of protection they need. RiSE comes to bridge the gap between the existing equity capital market for SMEs in Indonesia, equity crowdfunding and IDX acceleration board.

The paper contributes to the social, economic and business sciences. The results of this paper could be used by the government to formulate a regulatory environment which could support the growth of SMEs, by the SMEs to find another alternative source of fund, and by the investors to allocate their fund in SMEs investment.

This research only uses literature study and secondary data. Therefore, it is recommended to perform a further research using a more quantitative analysis to check the implication of having a stock exchange for SMEs for both retail investors and SMEs themselves.

\section{REFERENCES}

Agrawal, A., Catalini, C., \& Goldfarb, A. (2016). Are syndicates the killer app of equity crowdfunding? California Management Review, 58 (2), 111-124. 
Agrawal, A.K., Catalini, C., \& Goldfarb, A. (2013). Some simple economics of crowdfunding. National Bureau of Economic Research, 14 (1), 63-97.

AIM. (n.d.). Alternative investment market. Retrieved September 7, 2020, from https://www.londonstockexchange.com/raise-finance/equity/aim

Bursa Malaysia. (2019). Sustainability report 2019. Retrieved September 7, 2020, from https://www.bursamalaysia.com/sites/5d809dcf39fba22790cad230/assets/5e5c68045b7 11a4c6c4b9c9e/_FINAL_Bursa_SR19_Mid_Res_03012020.pdf

Catalist-Singapore Exchange (SGX). (n.d.). The ideal platform for fast-growing enterprises seeking a primary listing. Retrieved September 7, 2020, from https://www.sgx.com/securities/catalist

Chinext. (n.d.). Milestones. Retrieved September 7, 2020, from http://www.szse.cn/English/about/milestones/index.html

Ertimur, Y., Ferri, F., \& Muslu, V. (2011). Shareholder activism and CEO pay. Review of Financial Studies, 24 (2), 535-592.

Estrin, S., Gozman, D., \& Khavul, S. (2018). The evolution and adoption of equity crowdfunding: Entrepreneur and investor entry into a new market. Small Business Economics, 51 (1), doi: 10.1007/s11187-018-0009-5.

Google-A.T. Kearney Study. (2017, September). Indonesia Venture Capital Outlook 2017. Retrieved September 8, 2020, from https://www.thinkwithgoogle.com/_qs/documents/ 4881/TWG-APAC-Indonesia-VC-Outlook-2017-Report.pdf

Harwood, A. \& Konidaris, T. (2015). SME exchanges in emerging market economies: A stocktaking of development practices. World Bank Group: Policy Research Working Papers, doi.org/10.1596/1813-9450-7160.

Indonesian Stock Exchange. (2019). IDX Factbook 2019. Retrieved September 7, 2020 from https://www.idx.co.id/media/7703/factbook-2019-indesign-halaman-2.pdf

Japan Exchange Group. (2020). Mothers Global Information. Retrieved September 7, 2020, from https://www.jpx.co.jp/english/equities/products/foreign/mothers/index.html

Kuppuswamy, V., \& Bayus, B.L. (2013). Crowdfunding creative ideas: The dynamics of project backers in Kickstarter. UNC Kenan-Flagler Research Paper, no 2013-15, available at SSRN:http://ssrn.com/abstract=2234765

Ministry of Cooperatives and Small and Medium Enterprises. (n.d.). Perkembangan data usaha mikro, kecil, menengah (UMKM) dan usaha besar (UB) Tahun 2012 - 2017. Retrieved September 5, 2020, from http://www.depkop.go.id /data-umkm

Ministry of Cooperatives and Small and Medium Enterprises. (n.d). Perkembangan data usaha mikro, kecil, menengah (UMKM) dan usaha besar (UB) Tahun 2010 - 2015. Retrieved on July 10, 2020, from http://www.depkop.go.id/uploads/laporan/ 1580279084_Perkembangan\%20Data\%20UMKM\%20dan\%20Usaha\%20Besar\%20(U B)\%20Tahun\%202010-2015.pdf

Ministry of Cooperatives and Small and Medium Enterprises. (n.d). Perkembangan data usaha mikro, kecil, menengah (UMKM) dan usaha besar (UB) Tahun 2017 - 2018. Retrieved July 10, 2020, from http://www.depkop.go.id/uploads/laporan/1580223129 PERKEMBANGAN\%20DATA\%20USAHA\%20MIKRO,\%20KECIL,\%20MENENG AH\%20(UMKM)\%20DAN\%20USAHA\%20BESAR\%20(UB)\%20TAHUN\%202017 \%20-\%202018.pdf

Narbuko, C., \& Achmadi, A. (2009). Metodologi penelitian. Jakarta: Bumi Aksara.

Nasarudin, M.I., Surya, I., Yustiavandana, I., Nefi, A., \& Adiwarman. (2014). Aspek hukum pasar modal Indonesia. Jakarta: Kencana.

Peraturan Otoritas Jasa Keuangan Republik Indonesia Nomor 37/POJK.04/2018. Layanan urun dana melalui penawaran saham berbasi informasi (Equity Crowdfunding). Lembaran Negara Republik Indonesia Tahun 2018 Nomor 37. Jakarta. 
Santara. (n.d.). Urun Dana Investasi Bisnis UKM. Retrieved September 12, 2020, from https://santara.co.id/

Schwienbacher, A. (2019). Equity crowdfunding: Anything to celebrate?. Venture Capital, 21 (1), 65-74, doi: 10.1080/13691066.2018.1559010.

Sigar, K. (2012). Fret no more: Inapplicability of crowdfunding concerns in the internet age and the JOBS Acts safeguards. Administrative Law Review, 64 (2), 473-506.

Terry, H.P., Schwartz, D., \& Sun, T. (2015). The future of finance. Goldman Sachs Global Investment Research, p. 3, 8-18.

The Jakarta Post. (2019, December 18). Government wants more SMEs to go public. Retrieved September 9, 2020 from https://www.thejakartapost.com/news /2019/12/18/government-wants-more-smes-to-go-public.html

The Stock Exchange of Hong Kong Limited. (n.d.). Growth enterprise market. Retrieved September 7, 2020, from https://www.hkgem.com/root/e default.asp

The World Federation of Exchanges. (2018, October 2). An overview of WFE SME markets. Retrieved September 10, 2020, from https://www.worldexchanges.org/news/articles/world-federation-exchanges-publishes-report-global-smemarkets

Tripalupi, R. I. (2019). Equity crowdfunding Syari'ah dan potensinya sebagai instrument keuangan syari'ah di Indonesia. ADLIYA: Jurnal Hukum dan Kemanusiaan, 13 (2), 229-246.

Undang-Undang Republik Indonesia Nomor 20 Tahun 2008. Usaha mikro, kecil, dan menengah. Lembaran Negara Republik Indonesia Tahun 2008 Nomor 20. Jakarta.

Undang-Undang Republik Indonesia Nomor 8 Tahun 1995. Pasar modal. Lembaran Negara Republik Indonesia Tahun 1995 Nomor 8. Jakarta.

Victoria, A. O. (2020, February 05). Rata-rata pendapatan penduduk Indonesia setahun Rp 59 Juta. Retrieved September 10, 2020, from https://katadata.co.id/agustiyanti/ finansial/5e9a495de4ee7/rata-rata-pendapatan-penduduk-indonesia-setahun-rp-59-juta

Wilson, K.E., \& Silva, F. (2013). Policies for seed and early stage finance: Findings from the 2012 OECD financing questionnaire. OECD Science, technology and industry policy papers, no. 9, doi.org/10.1787/5k3xqsf00j33-en.

Wilson, K.E., \& Testoni, M. (2014, August 28). Improving the role of equity crowdfunding in Europe's capital markets. Bruegel Policy Contribution, 2014 (09), 1-14. 